\title{
The Effectiveness of Online Learning on Student Practicum Skills
}

\author{
Ulfa Farrah Lisa ${ }^{1, *}$ Feni Andriani ${ }^{1,}$ Dian Ahzaliza ${ }^{2}$
}

\author{
${ }^{1}$ Faculty of Medicine, Andalas University \\ ${ }^{2}$ Faculty of Engineering, University of Negeri Padang \\ ${ }^{*}$ Corresponding author. Email: ulfafarrahlisa@med.unand.ac.id
}

\begin{abstract}
The learning method is one of the supporting techniques for the achievement of graduate competencies. One of the ways is e-learning, which is called online lectures. The research objective is to determine the effectiveness of online learning on student practicum skills. This type of research is a quasi-experiment with a post-test only control group design. The statistical test used is the Mann Whitney test. The results shows that online learning is effectively carried out to improve student practicum skills with $p=0.000$. Online learning is useful for improving student practicum skills. Practical knowledge that is done online is a practicum that uses simple tools and can be done anywhere. Researchers feel it is necessary to do further research on the type of practicum that requires laboratory equipment to see its effectiveness in improving skills.
\end{abstract}

Keywords: Online learning, student practicum skills

\section{INTRODUCTION}

Improving the skills and competencies of health workers is the second strategy for the Integrated Management of Pregnancy and Childbirth (IMPAC) approach. Qualified midwives are produced by midwifery education institutions that are managed by paying attention to developments in science, technology, and regulations $[1,2]$.

The learning process involves cognitive, affective, and psychomotor elements. Each academic unit has a system to produce quality graduates. The higher education system is seen as a process that will have four main stages, namely input, process, output, and outcome [3].

Empowerment of the academic field emphasizes mastery of academic competence, namely the skills and abilities to apply concepts, theories, and principles of science in various aspects of life. Practical learning activities need to be carried out in such a way as to be effective and efficient. The learning methods and media chosen must vary in the implementation of practical learning [4].

Learning media conveys learning messages where the communication process occurs between students, lecturers, and teaching materials. Communication will not run without the help of means of getting messages or the media. Suitable media in learning can provide the same stimulus, compare experiences, and cause the same perception [5].

The learning method is one of the supporting success of the achievement of graduate competencies. One of the ways is e-learning, which is called online lectures. This online lecture is a form of an online study that is officially held. An online course is one of Kemenristekdikti's breakthroughs, becoming the Ministry of Education and Culture.

The 2017 New Media Consortium Horizon report found that the blended learning method is one of the short-term strengths that will drive technological advances in higher education in the next 1-2 years [6]. Also, blended learning is one of the main problems in teaching and learning in the EDUCAUSE Learning Initiative's 2017 annual survey on higher education [7].

PDITT (Pembelajaran Daring Indonesia Terbuka dan Terpadu)/ Open and Integrated Indonesian Online Learning, organized to answer problems to improve: the quality of higher education; access to quality higher 
education; higher education participation rates; flexible provision of quality higher education; and providing opportunities for students to receive quality higher education to achieve good Learning Outcomes from leading universities that have reliable learning process standards starting from preparation, learning, assessment, and follow-up.

Online learning is very encouraged in every university, especially during the COVID 19 pandemic, to prevent the transmission of COVID 19. Andalas University is one of the universities that applies online learning during the COVID 19 pandemic, including practicum learning.

This study aimed to determine the effectiveness of online learning on student practicum skills in the Undergraduate Midwifery Study Program, Faculty of Medicine, Andalas University

\section{METHODS}

The type of research used in this study is a quasiexperiment with a post-test only control group design. The research subjects were given treatment, namely the blended learning method.

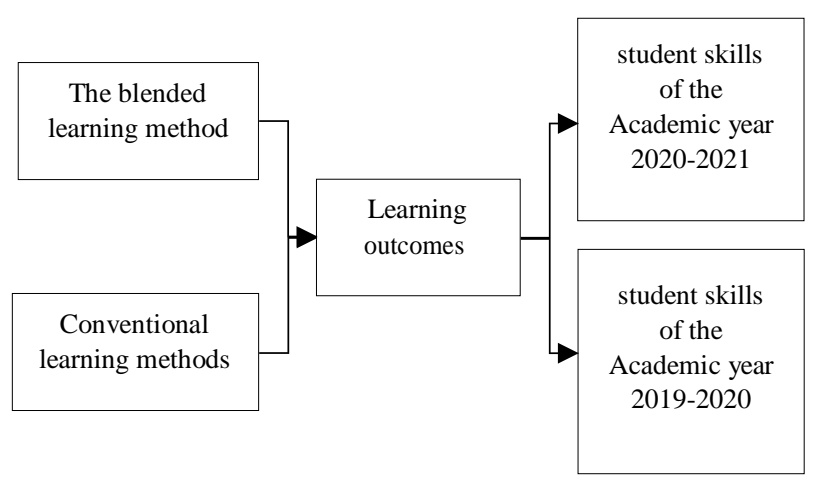

Figure 1. Research design

Intervention research subjects were all students of the 2020-2021 academic year, and the control was all students of the 2019-2020 academic year of the Undergraduate Midwifery Study Program who took Block 5A. Professional ethics, health law, politics, and policy in midwifery. The model applied in this research is the blended learning method using instructional videos. The analysis used to test the hypothesis is to look at the difference in the mean (average) data of the treatment group (this year) and the control group (last year) to determine whether the effectiveness of online learning on student practicum skills through the unpaired Test (T) test with CI $95 \%$.

\section{RESULTS AND DISCUSSION}

\subsection{Results}

Table 1 The effectiveness of online learning on student practicum skills

\begin{tabular}{lccc}
\hline $\begin{array}{c}\text { Student practicum } \\
\text { skills }\end{array}$ & $\begin{array}{c}\text { Intervention } \\
\text { Group }\end{array}$ & $\begin{array}{c}\text { Control } \\
\text { Group }\end{array}$ & p value \\
\hline Mean & 96,67 & 89,48 & \\
SD & 1,10 & 6,65 & 0,000 \\
Median & 97 & 90 & \\
Range & $95-98$ & $75-100$ &
\end{tabular}

Based on the table above, it was found that the practical skills score of students in the intervention group, namely students in 2020-2021 who used the online learning method, had a greater mean of 96.67 compared to the mean in the control group of 89.48 days, with a range of values in the intervention group of 95. -98 and the range of values for the control group was 75-100. Statistical tests using the unpaired T-test showed a significant difference in practicum values between the intervention and control groups, with a pvalue of 0.000 .

\subsection{Discussion}

This research was conducted on essential practicum learning, which is about necessary communication, how to wash hands effectively, and how to wear sterile gloves. This skill is very minimal; using laboratory equipment and tools to wear sterile gloves can be purchased at drugstores so that this learning can be done online.

Learning is carried out through the Andalas University e- learning page. Online learning is carried out using discussion forums, learning videos, and video conversions. Researchers have developed an OBE-based blended learning semester learning plan and learning media in communication practicum learning videos, effective hand washing, and wearing sterile gloves.

Clinical skills education in midwifery programmes typically involves the use of a skills lab, which contains relevant equipment and provides an opportunity for students to see a demonstration of the skill face-to-face before practicing it under supervision, sometimes repeatedly. After this, they are able to consolidate performance of the skill under the supervision of a midwifery mentor in practice [8]. Educators are increasingly compelled to consider innovative approaches to teaching and learning strategies within the curriculum. Questions the use of more traditional, didactic forms of skills teaching and suggests that this approach does not foster essential critical decisionmaking skills, as students are not encouraged to incorporate their knowledge and understanding of the underlying evidence base [9].

There is also a significant shift towards the use of simulation for skills teaching, occurring in authentic environments and incorporating opportunities for reflection. Simulation for skills teaching has been found 
to bridge gaps between theory and practice, and positively affect how prepared and confident the student midwife feels to apply knowledge and skills in the practice setting [10].

Advances in technology allow educators to consider using an active blended approach to facilitate the teaching and learning of a clinical skill. A modified approach to the traditional face-to-face method of delivering, this structured teaching strategy involves the use of video assisted technology, embedded into an online learning unit that students can access remotely.

The effectiveness of blended learning is complex and dependent on how well the evaluation fits, since it occurs before the implementation of any innovation as well as allowing planners to determine the needs, considering participant characteristics, analyzing contextual matters, and gathering baseline information [11].

Video media can make students work independently; students can watch videos while following manual actions, answer questions before practicing, do practicum skills, and finally assess what has been done. The function of video media in cognitive terms can facilitate goals to understand and remember information or messages and help understanding and memory content for students who are weak in reading. The results of Ulfa Farrah Lisa's research showed that video media had a significant effect on students' knowledge and skills [12].

Research results of Dziuban, $\mathrm{C}$ et al. In each case, irrespective of the marginal probabilities, those students conforming to the rule have a virtually $100 \%$ chance of seeing the course as excellent. For instance, $27 \%$ of all students expecting to fail assigned an excellent rating to their courses, but when they conformed to the rule the percentage rose to $97 \%$. The same finding is true when students were asked about their desire to take the course with those who strongly disagreed assigning excellent ratings to their courses $26 \%$ of the time. However, for those conforming to the rule, that category rose to $92 \%$. When course modality is considered in the marginal sense, blended learning is rated as the preferred choice. However, from Table 6 we can observe that the rule equates student assessment of their learning experiences. If they conform to the rule, they will see excellence. Blended learning will be a substantial change in higher education and impact future education methods due to its flexibility, allowing us to maximize the many positive functions of education. [13]

Based on the results of Rahmansyah Irhasyuarna's research data analysis, the average pre-test score, the post-test score, N-gain, and the level of attainment of practicum skills, in the experimental class having high criteria obtained an $\mathrm{N}$-gain of $50 \%$, moderate $47.4 \%$, and low at $2.6 \%$. All practical courses almost reached the high standards. Meanwhile, the control class has an $\mathrm{N}$ gain price at high $10.5 \%$, medium at $84.2 \%$, and low at $5.3 \%$. The difference in $\mathrm{N}$-gain percentage on the high and low criteria for the experimental class is $50 \%$. The practical course on short standards has an $\mathrm{N}$-gain rate of $2.6 \%$, while for high bars, it has an $\mathrm{N}$-gain percentage of $50 \%$. This is shows that the experimental class on low criteria can still be guided to develop practical skills [14].

Blended learning is carried out through live discussions using audio-conferencing, interactive video conferencing, real-time chat consoles, and various variations. Learning materials can be downloaded and studied in advance in the form of text, audio and video. Students can ask directly with the instructor providing material, consult on an idea and understanding, and build personal closeness. Even though they have never met face-to-face, they feel they directly correspond to the instructor. This can occur because of direct interaction, although only communication signals are connected virtually. Fellow students provide support, feedback, and suggestions for the progress of each student. Therefore, it is very significant to be applied to practicum learning to improve student skills and the study program's competency attainment.

\section{CONCLUSION}

Online learning is useful for improving student practicum skills. Practical knowledge that is done online is a practicum that uses simple tools and can be done anywhere. With the online method, students practice more often before making skill videos for practicum examination assessments. Also, the psychological level in facing the exam without being observed by the examiner is more relaxed than the direct test. However, researchers feel that further research is needed on the type of practicum that requires laboratory equipment to see its effectiveness in improving skills.

\section{ACKNOWLEDGMENT}

This research goes well with the support of funding from LPPPM Andalas University. On this occasion, the authors would like to thank the LPPPM for funding this research, so that this research produces results that can be published in ICED QA III and the results can also be applied in the learning process in the midwifery study program of the Medical Faculty Of Andalas University.

\section{REFERENCES}

[1]WHO. Integrated Management of Pregnancy and Childbirth (IMPAC). Maternal, Newborn, Child and Adolescent Health: www.who.int; 2013

[2] Kementerian-Kesehatan-RI. Kurikulum Inti Pendidikan D-III Kebidanan. In: BPPSDM, editor. Jakarta: Bakti Husada; 2011 
[3] Sub_Direktorat_KPS. Buku Panduan Pengembangan Kurikulum Berbasis Kompetensi Pendidikan Tinggi. In: Direktorat-AkademikDirektorat-Jenderal-Pendidikan-Tinggi, editor. Jakarta2008.

[4] Nursalam, Efendi F. Pendidikan dalam Keperawatan. Angriani R, editor. Jakarta: Salemba Medika; 2009.

[5] Simamora RH. Buku Ajar Pendidikan Dalam Keperawatan. Tiar E, editor. Jakarta: EGC; 2009.

[6] Adams Becker, S., Cummins, M., Davis, A., Freeman, A., Hall Giesinger, C., \& Ananthanarayanan, V. (2017). NMC horizon report: 2017 higher Education Edition. Austin: The New Media Consortium

[7] EDUCAUSE. (2017) 2017 key issues in teaching \& learning. $\quad$ Retrieved from https://www.EDUCAUSE.edu/eli/initiatives/ keyissues-in-teaching-and-learning

[8] Bloomfield JG, Cornish JC, Parry AM, Pegram A, Moore JS. Clinical skills education for graduate- entry nursing students: Enhancing learning using a multimodal approach. Nurse Educ Today. 2013; 33(3): 247-52. https://doi.org/10.1016/j.nedt.2011.11.009

[9] Rutt J. Pre-registration clinical skills development and curriculum changes. Br J Nurs. 2017; 26(2): 93-7. https://doi.org/10.12968/ bjon.2017.26.2.93

[10] Lendahl L, Oscarsson MG. Midwifery students' experiences of simulation-and skills training.Nurse Educ Today. 2017; 50: 12-16. https://doi.org/10.1016/j.nedt.2016.12.005

[11] Kintu MJ, Zhu C, Kagambe E. Blended learning effectiveness: the relationship between student characteristics, design features and outcomes. Int J Educ Technol High Educ 2017 Feb 6;14(1):1-20. [doi: 10.1186/s41239-017-0043-4]

[12] Lisa, Ulfa F. The Effect of Using Video Media in Skill Laboratory for Students Knowledge and Skill in Managing Shoulder Dystosia at Ubudiyah Indonesia University. Journal Of Healthcare Technology and Medicine Universitas Ubudiyah Indonesia Vol. 1 No. 1 April 2015 ISSN 2442-4706

[13] Dziuban, $\mathrm{C}$ et al. Blended learning: the new normal and emerging technologies. International Journal of Educational Technology in Higher Education (2018) 15:3 DOI 10.1186/s41239-017-0087-5

[14] Rahmansyah and Irhasyuarna, Y. Implementasi model blended learning terhadap keterampilan generik pemodelan dan hasil belajar siswa pada materi kelarutan dan hasil kali kelarutan. QUANTUM, Jurnal Inovasi Pendidikan Sains, Vol.7, No.1, April 2016, hlm. 74-82 